\title{
H R Trevor-Roper vs. Arnold Toynbee: A post-Christian Religion and a new Messiah in an age of reconciliation?
}

\author{
Frederick Hale $^{1}$ \\ (University of Pretoria)
}

\section{ABSTRACT \\ H R Trevor-Roper vs. Arnold Toynbee: A post-Christian Religion and a new Messiah in an age of reconciliation?}

That the twentieth century witnessed massive secularisation in Europe and certain other parts of the world is beyond dispute, as is the fact that the general phenomenon of religion and its role as a factor shaping history remain potent on a broad, international scale. There is no consensus, however, about the future place or status of Western Christian civilisation or "Christendom" in a shrinking and pluralistic world also struggling with the challenge of reconciliation. During the 1950s two controversial giants of British historiography, Arnold Toynbee and $H R$ Trevor-Roper clashed on this issue. Their severe differences of opinion were conditioned in part by the Cold War, general retreat of imperialism from Africa and Asia, and the growth of the economic, military, and political power of previously colonised or otherwise subjugated nations.

\section{INTRODUCTION}

The vicissitudes of the twentieth century, especially the two world wars which splashed the blood of tens of millions of victims across its first half, convinced many European scholars that Western or Christian civilisation might be in its final phase. Their predictions of its demise were not entirely novel; similar prognostications had been made well before 1900. However, increasing fragmentation, chauvinistic nationalisms, the clash of ideologies, the march of secularisation, the lack of tolerance and reconciliation, and other tendencies gave renewed currency to the general view that Christendom, at least in its European manifestation, had largely had its day. Eventually the retrospective

1 Research associate in the department of Church History and Church Polity, University of Pretoria. 
Dutch theologian Anton Wessels would write a treatise which in its English translation was tellingly titled Europe: Was it Ever Really Christian? (Wessels 1994), and in his encyclical of 1981 Familiaris consortio Pope John Paul II proclaimed the need for "a new evangelisation of Europe”. Meanwhile, modernisation in numerous Asian countries, the waning of overt European colonialism, and the rise of the Soviet Union and Africa also posed challenges to the seeming invincibility and permanent global domination of the West.

Among the most widely noted heralds of its impending decline was the eminent historian Arnold Toynbee of the University of London, whose Lebenswerk in twelve volumes, A Study of History, was published by Oxford University Press between the 1930s and the 1960s. Based in large measure on a highly controversial theory of "challenge and response", this massive survey of twenty-six civilisations sought to demonstrate the recurrent features in their rise and fall. Toynbee, like many of his colleagues, believed that the course of history tended to follow certain laws or at any rate adhered to distinct patterns. Other historians disagreed and insisted that it did not, i.e. that an ever-changing matrix of factors made the chronological flow of events and phenomena unpredictable.

Toynbee always had his critics, such as Professor Pieter Geyl of the University of Utrecht, who rejected the cyclical approach outright. To this Dutch scholar, Toynbee's general approach to history was artificial and unempirical. Indeed, in 1954 he went so far as to deny that Toynbee was a historian at all, calling him instead a "prophet" whose "prophecy” was “a blasphemy against Western Civilization” (cf Geyl 1955:178). Nevertheless, in the eyes of his devotees he was a historiographical genius and A Study of History was revered as a monumental interpretation of the progress and regress of the human species as a social creature.

Toynbee, like many other critical observers of the twentieth century, was disillusioned by much that had happened in recent centuries and suggested that in some respects the Middle Ages were the high-water mark of European civilisation before the humanism of the Renaissance and the religious fragmentation of the Reformation effectively terminated the greater degree of social harmony which had earlier prevailed. This position was, of course, rejected by many 
humanists, people of liberal ideological bent, foes of Roman Catholicism, and others who found the contemporary world essentially compatible with their beliefs and attitudes. Moreover, in the wake of the Second World War, the continuing threat of the Soviet Union during the years of the Cold War made any suggestion that the West would not prevail seem to smack of cultural and/or political betrayal. Toynbee's 1952 Reith Lectures, in which he tried to explain that the West had not always played an innocent rôle on the stage of global history and why, in consequence, European imperialism was resented in Asia, Africa, and elsewhere, therefore did not meet with a universally warm reception. As I have demonstrated elsewhere, much of the ensuing polemic over Toynbee's controversial lectures, titled "The World and the West", was led by the ever-antagonistic English Roman Catholic historian, publisher, and man of letters Douglas Jerrold, who countered with a hard-hitting book titled The Lie about the West, in which he argued inter alia that Western civilisation, under the aegis of Christianity, was divinely ordained and thus must endure (Hale 2004:23-24).

The debate reached another level in 1957 when an abridgement of the sixth through tenth volumes of $A$ Study of History appeared under the imprint of Oxford University Press. By that time, one can safely generalise, most professional historians in Europe did not hold Toynbee, despite his vast erudition, in high esteem as an interpreter of world history. Nevertheless, the newly appointed Regius Professor of Modern History at the University of Oxford, Hugh Redwald TrevorRoper, thought it necessary to administer the coup de grâce to Toynbee's reputation in a lengthy and intensely critical article published in the monthly London review Encounter. This critique and the ensuing debate are relevant to church history because Trevor-Roper (who regarded himself as inter alia a church historian, partly on the strength of his acclaimed biography of William Laud) accused Toynbee, who had great respect for much in Christianity while being what one of his sympathetic biographers called "a deeply religious agnostic", of advocating a syncretistic religion to succeed it and, no less, of believing that he would be the messiah of this new faith (cf Orr 1986:858). Surprisingly enough, this clash between two eminent scholars who many of their colleagues grudgingly acknowledged were 
among the greatest of all British historians, has never been given its due. In standard biographies of Toynbee it is either glossed over or neglected entirely. It is my purpose in the present article to redress this neglect by analysing Trevor-Roper's criticism of Toynbee in its historical context, paying particular attention to the place of the religious dimensions of the verbal assault.

\section{TOYNBEE'S RELIGION}

Where did Toynbee stand personally with regard to Christianity? Beginning in the 1930s, commentators called attention to Toynbee's keen interest in religions, including what he regarded as their crucial rôle in the formation, maintenance, and regeneration of civilisations. One need not read far into virtually any volume of $A$ Study of History to find numerous references to this general aspect of human behaviour. Furthermore, in places Toynbee's interpretation of world history is expressed in Biblical and other Christian terms. His study of the saga of mankind did not leave him in doubt that " Original Sin' which is innate in terrestrial human nature" was a chief cause of the decline of civilisations. Similarly, Toynbee declared unabashedly that "this World is a province of the Kingdom of God, but it is a rebellious province, and, in the nature of things, it will always remain so" (Toynbee 1960:675-677). The Christian message of divine love offered at least a partial solution on an individual basis, he thought, although he did not expect the proliferation of Christianity to invalidate what he believed was a virtually immutable law of the rise and decline of civilisations as such. "Our evidence declares that Man does not live under one law only; he lives under two laws, and one of these two is a Law of God which is Freedom itself under another and more illuminating name," Toynbee concluded. Referring explicitly to the Epistle of James, he stated that the "perfect law of liberty" is a "law of Love". It had been given to the human species "by a God who is Love in person" and could be used "for freely choosing Life and Good, instead of Death and Evil, only if Man, on his side, loves God well enough to be moved by this responsive love of his to commit himself to God by making God's will his own” (Toynbee 1960:857).

There is some degree of irony in this. To be sure, Toynbee was raised an Anglican, and he never formally left the Church of England. Yet at an early point he distanced himself from much orthodox 
Christian doctrine and, as early noted, his personal spirituality was marked by agnosticism with regard to a commitment to the existence of a Supreme Being. That did not prevent Toynbee, however, from perceiving world history as subject to God. When writing several volumes of A Study of History after the Second World War, moreover, he reportedly became "more religious, even mystical, in outlook, and grew closer to Catholicism”(Millar 2004:183). The last-named element of his spirituality was apparently not entirely novel. In the mid-1930s Toynbee had enrolled his troubled son, Philip, who had been expelled from Rugby, at the Benedictine public school at Ampleforth in Yorkshire (Fermor \& Taylor 2004:190).

\section{H R TREVOR-ROPER: THE MAKING OF A POST-EN- LIGHTENMENT MESSIAH}

Part, though certainly not all, of Trevor-Roper's hostility to Toynbee's pessimistic attitude towards the future of Western civilisation arguably lay in the former's privileged social status therein. Born into the northern English aristocracy in 1914, he was educated at Charterhouse before going up to Oxford, where he studied at Christ Church and earned his baccalaureate degree in modern history in 1936. While delving into the past during those three years, Trevor-Roper cultivated ties with the jeunesse dorée which confirmed his bourgeois anchoring and helped to assure his professional future. Appointed a research fellow at Merton College in 1937, he never completed a doctorate, as the Second World War interrupted his scholarly career. This proved professionally auspicious, however, as the multilingual Trevor-Roper entered the intelligence service and shortly after the conclusion of hostilities in Germany succeeded in interviewing many of the Führer's close associates, an assignment which led to his highly readable and critically lauded The Last Days of Hitler in 1947. Having in the meantime returned to Oxford, the increasingly prominent young scholar taught at Christ Church where, as recalled by one of his colleagues, he

"was a stimulating teacher for those to whom he took a liking, and he created for himself a university-wide reputation as an antagonist of dullness and mediocrity” (The Times, 27 January, 2003:8).

After eleven years of moderate scholarly productivity in this capacity, Trevor-Roper was appointed by Prime Minister Harold Macmillan in June 1957 to succeed V H Galbraith as Regius Professor 
of Modern History, a move which surprised many observers both within and outside British academe who assumed that a more senior colleague, such as the left-leaning A J P Taylor, would get the nod (The Times, 6 June, 1957:10). The extent to which the appointment of Trevor-Roper was politically motivated has been debated. In any case, it was later generously recalled that the young and unabashedly brash historian "continued to be the brilliant lecturer and research supervisor he had begun to be at Christ Church" and that he had "confounded predictions by being both a courteous and an effective chairman of the Oxford history faculty” (The Times, 27 January, 2003:8).

Immediately after his appointment had been announced, TrevorRoper was interviewed in Oxford and signalled his commitment to broader scholarship which, at least on the surface, might have seemed sympathetic to Toynbee's inclusively defined agenda. "The amount of man-hours wasted in useless research is depressing", he confessed. "Modern specialization has become much too narrow. I think there is too much period specialization here. The unity of history is provided by historical problems and not by period problems" (The Times, 7 June, 1957:12).

Trevor-Roper's attitude towards Christianity undoubtedly also played a rôle in his stance vis-à-vis Toynbee's fatalistic view of Western Christian civilisation. On the one hand, the eminent Oxford professor was certainly no exponent of theological orthodoxy or enthusiast for the institutional church. As one of his associates put it when attempting to understand the roots of his position regarding religion in general, "It is not certain whether Trevor-Roper was overwooed as a young man by the Oxford Jesuits, or whether there were other reasons for his enmity to religious orthodoxy, both Christianity and Rabbinical”. In any case, to this commentator Trevor-Roper's underlying hostility to the Church of Rome was patent; his "guiding instinct was the rationalist instinct to identify Roman Catholicism with Marxism or Cardinal Bellarmine with Himmler, and to put the worst possible interpretation on the fact that, without the Church, Christianity would not have survived" (The Times, 27 January, 2003:8). According to one of his disciples at Oxford, Kevin Sharpe, who subsequently became a noted historian of the Renaissance, the "not particularly pious" Trevor-Roper was attracted to the Church of England essentially 
"as a bastion of order and cohesion" and because in Anglican circles he found a generally tolerant atmosphere reminiscent of the Enlightenment and not limited to any one doctrinal direction. With regard to his erstwhile mentor's "anticlerical streak", Sharpe recalled that as the newly appointed Master of Peterhouse, Cambridge, in 1980, TrevorRoper had responded to a query about how he would relate to the High Church tradition of that college by noting that he would "bow down in the house of Rimmon"(Sharpe 2004). Elsewhere, Sharpe remembered that Trevor-Roper had been "the enemy of orthodoxies and ayatollahs", a man who preferred "humanist writers and thinkers who, in an age of religious zeal and warfare, endeavoured to preserve Christendom and the civilised community of letters", such as Thomas More and Erasmus of Rotterdam. He also noted with gratitude that the eminent Oxford historian had insisted that in order to understand seventeenth-century Europe, he develop a "familiar acquaintance with the Bible" (Sharpe 1993:4-5).

Trevor-Roper's attitudinal captivity within European civilisation is also underscored by his attitude towards Africa. In a televised lecture of 1963 which has haunted his reputation endlessly, he belittled the demands of undergraduate students at his venerable institution who had supposedly succumbed to the winds of "journalistic fashion" and were calling for the establishment of courses in African history. "But at present there is none," he proclaimed magisterially, allowing that "perhaps, in the future, there will be some African history to teach. But at present there is none: there is only the history of Europeans in Africa". Trevor-Roper sought to justify this seemingly severe Eurocentric dismissiveness by explaining his conviction that history is "essentially a form of movement, and purposive movement too", and such a progression he could not perceive in the African past. This Englishman ridiculed and caricatured suggestions that we "neglect our own history and amuse ourselves with the unrewarding gyrations of barbarous tribes in picturesque but irrelevant corners of the globe" (Trevor-Roper 1963: 871).

\section{TREVOR-ROPER'S CRITICISM OF TOYNBEE}

Trevor-Roper's assault on A Study of History was occasioned by the publication early in 1957 of the second volume of David C Somervell's abridgement of those ten volumes which had appeared at that time. 
(The first part of the abridgement, which appeared in 1946, encapsulated volumes I through VI). Like its predecessor, this one sold very well and was widely heralded in many reviews, including some written by other professional historians, although by that time Toynbee's star had certainly fallen in the eyes of many of his colleagues in the United Kingdom and overseas. The ongoing popularity prompted a variety of reactions by historians in 1957, of which Trevor-Roper's was not entirely representative. Writing in a much more restrained vein, for example, Professor Hans Kohn of City College of New York, an eminent Jewish historian originally from Prague, wrote a short volume titled Is the Liberal West in Decline? in which he strongly took issue with Toynbee's pessimistic perception of the recent and anticipated downward course of Occidental civilisation (Kohn 1957:33-43).

Trevor-Roper's criticism differed from those of most others, however, in its professed purpose if not necessarily in terms of its overall negativity. “Arnold Toynbee's Bible - for so one can reasonably describe his ten-volume Study of History - has not been well received by the professional historians", he sniffed in overgeneralised terms which hardly did justice to the mixed reception that work had long received. Having launched his attack with this salvo, Trevor-Roper immediately stated his own fundamental position: "I agree with them in regarding it as untrue, illogical and dogmatic". Stacking one sweeping generalisation upon another, the Regius Professor designate declared that "every chapter of it has been shot to pieces by the experts" and lampooned Toynbee's style by insisting that compared thereto "that of Hitler or Rosenberg is of Gibbonian lucidity". His own task, however, was not to point to the numerous errors which marred the text, as that, in his view (and, no doubt, in those of many other scholars) would have been redundant. Instead, Trevor-Roper took it upon himself to evaluate $A$ Study of History as "a document of our time" and to "ask why such error has such a vogue". "What is the meaning of Toynbee's message in the context of our time?" he asked. "What kind of a future does Toynbee (rightly or wrongly) envisage? What part, in the unfolding of history, does he invite us to play?” (Trevor-Roper 1957:14). 
In seeking to answer these questions, Trevor-Roper cast what he interpreted as the general message $A$ Study of History in a mould of religious language, suggesting that Toynbee had preached a millenarian, cataclysmic version of the course of history. His proclamation, like that of the Scriptures of the Judaeo-Christian heritage, had been revealed in two essential parts. Trevor-Roper designated the first six volumes of A Study of History as the "Old Testament", which was published during the 1930s. Toynbee's "New Testament", i.e. the seventh through tenth volumes of the same work, had appeared in 1954. Continuing his metaphor, Trevor-Roper noted pointedly that the last of these tomes, which he called the "Book of Revelation", was particularly remarkable, as it "sheds a great deal of light on the purpose and character of the whole work". Comprehension of the entire study, in his view, depended on reading the entire canon sequentially, "beginning with Genesis and ending with Revelation" (Trevor-Roper 1957:14).

Like the first book of the Pentateuch, Trevor-Roper surmised, the initial volume of $A$ Study of History detailed the fall - not simply of Adam, but "the Fall of Civilisations". In a reasonably fair recounting of Toynbee's overarching theory of the course of successive civilisations, he summarised that the study argued that in very general terms they all follow a pattern, though with great variations in it, of flourshing and decaying - and ultimately dying. There was thus a dire lesson for twentieth-century European readers, Trevor-Roper pointed out: "Always there is an end, and our own Western Civilisation, which we once thought unique and immortal, is in fact no different from the others. It too must die. As a matter of fact, it must die very soon. Has it not already shown all the signs of senility, as diagnosed by the scientific doctor of civilisations?” (Trevor-Roper 1957:14-15).

Focussing on Toynbee's portrayal of the course of Western civilisation, Trevor-Roper disagreed sharply with what he thought were underlying flaws in the analysis. To begin with, the Regius Professor, given his Enlightenment convictions, rejected the "determinist" quality of the general theory, especially because it ran counter to the principles of free will and the power of the human mind. "In spite of its Hellenic training”, he wrote with reference to Toynbee's early education in Graeco-Roman cultures and languages, "his mind is fundamentally 
anti-rational and illiberal. Everything which suggests the freedom of the human reason, the human spirit, is to him odious”. Trevor-Roper consequently found Toynbee's dating of the beginning of the decline of Western civilisation particularly objectionable, namely "from the time when our ancestors ate the fruit of the Tree of Knowledge and sought to be like gods, knowing good and evil - the time of the Renaissance". The two distinguished historians were thus poles apart in their perception of turning points in the annals of Europe: "Europe's greatest centuries, the centuries of the Reformation, the New Philosophy of the $17^{\text {th }}$ century, the enlightenment, the gradual conquest of disease and famine, are to him its darkest ages”, Trevor-Roper lamented (TrevorRoper 1957:15).

The scant hope that Toynbee had offered in his "Old Testament" for reversing the downward slide of the past several centuries also ruffled the feathers of Trevor-Roper's humanist sentiments. "The best we can do is to find our way back into that Paradise of medieval innocence from which, by our fatal presumption, we have been expelled", he scoffed. "Since it was the Renaissance and the Reformation which, by opening the eyes and the mind of man, set us on the 400-year slope leading to destruction, let us now seek to go back behind those fatal episodes, deny them and their consequences, [and] pretend that they have never been”. Given his hostility to religious authoritarianism, Trevor-Roper was particularly irked that this hypothetical reversal of historical trends would necessitate submission to the discipline of the Roman Catholic Church, and he expressed his reaction thereto sarcastically: "Who knows but that holy old hen, Mother Rome, though understandably somewhat stand-offish after such long insubordination, may consent to sit again upon her naughty but now penitent brood?” Granted, such a scenario would not ultimately prevent the demise of the West, but it might mitigate its consequences, Trevor-Roper added tongue-in-cheek. "By sin came death. We cannot now escape the decree of death; but at least let us repent of our sin" (Trevor-Roper 1957:15-16).

Moreover, for all his erudition, Toynbee, in his fixation on the supposed inevitability of the decline of Western civilisation, had failed to recognise that it had been subjected to enormous pressure in past centuries but made remarkable comebacks. Trevor-Roper linked the 
greatest of these to the history of Christianity. In the sixteenth century, he pointed out, the frontiers of Christendom shrank as the Ottoman Empire expanded far into Europe. The Turkish advance claimed such Christian cities as Belgrade and Budapest as well as various Mediterranean islands which had long been under the influence of the church. Pessimistic voices, including "the Toynbee of those days, Pope Clement VII", said the end of the Christian era was at hand. In retrospect, Trevor-Roper judged, the century of the Renaissance and the Reformation was "the beginning of the greatness of the West". How absurd, he thought, that "to Toynbee, who regards the greatness of the West as its decay, the $16^{\text {th }}$ century is the beginning, not the end, of the process” (Trevor-Roper 1957:27).

Trevor-Roper found a chasm separating the first six from the next four volumes of A Study of History, one caused by the tectonic force of the Second World War which, he believed, had required Toynbee to revise his general theory significantly, though without acknowledging that he was doing so. Toynbee's “Old Testament”, he argued, had a "German pedigree", incorporating a determinist, catastrophic view of history in harmony with those variously propounded by such men as Georg Wilhelm Friedrich Hegel, Karl Marx, Friedrich Nietzsche, and Oswald Spengler, all of whom had predicted either the imminent or the eventual demise of Western civilisation. Adolf Hitler, too, had envisaged its end but had cast himself in the lead rôle in the crusade to overthrow it in favour of a New Order. With his "dismal certitudes", Toynbee was thus "the unconscious intellectual ally of Hitler in the non-Nazi world”. Extending his retrospective accusation, Trevor-Roper acknowledged that although Toynbee had not evinced any particular love for Germania, he "seems not to care who destroys the West, so long as the West is destroyed and thus vindicates his theory". However, the resilience of that ostensibly doomed civilisation in the face of the Blitzkrieg had at least temporarily confounded the prognostication. Rather than conceding that he had erred, Toynbee had merely noted in 1954 that his "inner world" had undergone "changes" of some magnitude. A public greater confession, Trevor-Roper suggested, would be too much to expect of any "prophet" (Trevor-Roper 1957:1618). 
The face-saving "escape-clause”, Trevor-Roper thought, lay first in Toynbee's downplaying the force of the Third Reich. Its perceived military might was thus considerably less than Hitler's Allied foes had thought-necessarily so, according to the logic of his theory, but had it not been so it would have been sufficiently powerful to overcome the decadent West. Furthermore, an "accidental combination of incidental errors" had prevented the Third Reich from playing a more lasting and determinative part on the stage of European history. Beyond this, however, in his post-1945 presentation of the history of civilisations, Toynbee had shifted gears and begun to argue that parts of civilisations could survive their general demise and manifest themselves in new, amalgamative civilisations, or in "universal states" which succeed them. The question looming above all others thus becomes what elements of Western civilisation will be incorporated in a new, composite one? (Trevor-Roper 1957:18-20).

Certainly not most of our secular culture, in Trevor-Roper's reading of Toynbee. "Our political forms, our liberties, our cultures shall be crushed out. But what of that?" he ridiculed his target. Rather, parts of the specifically Christian heritage would endure, albeit subordinated in a new kind of faith: "For our religious beliefs, which alone matter, will be preserved, pickled as one of the ingredients of a new syncretist religion, a new tutti-frutti, 'a mish-mash', as one commentator has described it, 'of the Virgin Mary and Mother Isis, of St. Michael and Mithras, of St. Peter and Muhammed, of St. Augustine and Jalal-ad-Din Mawlana'”. Despite his rejection of Christian orthodoxy, Trevor-Roper abhorred the prospect of such a "universal religion" replacing both Christianity as a discrete belief system and "the use of human reason and the remembrance of its great landmarks, the Renaissance, the Reformation, the New Philosophy, the Enlightenment” (Trevor-Roper 1957:20).

Despite his intemperate language, Trevor-Roper was on at least partially solid ground in his portrayal of Toynbee's view of the future of religion generally, although that expansive topic could not be reduced to the simple formula in which the former represented it. Three years earlier Toynbee had responded to a review in The Times Literary Supplement of Douglas Jerrold's The Lie about the West, a short volume in which that prominent amateur historian, a Roman Catholic 
who had been a staunch cultural conservative since the 1930s, had severely criticised his 1952 Reith Lectures as essentially defeatist and inimical to the future of Christian civilisation. In his reply, Toynbee had addressed in broad terms the reviewer's query about the changing face of religion as Christendom receded. "I guess that the West is going to be converted to some religion which, like Mahayanian Buddhism, Mithraism and Christianity, calls on us to worship a god who is not a deification of our human selves", he had stated. "Since the close of the seventeenth century we Westerners have been progressively substituting for Christianity one form of man-worship: a cult of individual liberty on a secular, instead of a Christian, basis” (Toynbee 1954:249). This answer, however, was hardly identical with the syncretistic "mishmash" Trevor-Roper had accused him of predicting and even advocating.

At any rate, the Regius Professor ventured far out on thin ice in speculating on Toynbee's self-ascribed role in the creation and maintenance of a "universal religion". Trevor-Roper explained that any new faith needed what he termed a "messiah" figure. Insisting that he was "serious", he disclosed who that would be: "In the tenth volume of his work, the last book of his Bible, his Book of Revelation, the secret is laid bare: the Messiah steps forth: he is Toynbee himself”. This new saviour would inter alia know the laws governing human history and could predict the form the new religion would take. Trevor-Roper constructed his case for this deduction essentially on the basis of autobiographical excerpts culled from the ninth and tenth volumes of $A$ Study of History. Lampooning Toynbee's habit (which, to be sure, had irked numerous reviewers through the years) of announcing in print where and when he had experienced various epiphanies about historical events and trends, Trevor-Roper quoted several such instances. Toynbee had disclosed, for example, that a few details of how he had swum the Euphrates as a young man, succeeded in writing a better essay than his schoolmates, come to a greater understanding of determinism and free will while watching a puppet show in Osaka, Japan, in 1929, and, in the most extreme example, had recalled the following quasi-mystical incident:

In London in the southern section of Buckingham Palace Road, walking southward along the pavement skirting the west wall of 
Victoria Station, the writer, once, one afternoon not long after the end of the First World War, had found himself in communion, not just with this or that episode in History, but with all that had been, and was, and was to come. In that instant he was directly aware of the passage of History gently flowing through him in a mighty current, and of his own life welling like a wave in the flow of this vast tide (Toynbee 1954:139).

These and several excerpts are strung together ad nauseum in the construction of the case against Toynbee's modesty. Trevor-Roper also found evidence of excessive egotism in the index to the last four volumes of A Study of History, where the entry "Toynbee, Arnold Joseph" spanned no fewer than twelve column-inches, while other entries were made for fully a dozen other members of the Toynbee clan. All of this, and more, which Trevor-Roper gleaned from those volumes undergirded his conviction that Toynbee regarded himself as the Messiah of a new faith whose very being had run parallel to that of Jesus Christ:

Tucked away in the corners of his New Testament, we can find the authentic record of everything that matters in his Life; the minor prophets who dimly heralded his coming; the Holy Family; the precocious Infancy; the youthful Temptations; the missionary Journeys; the Miracles; the Revelations; the Agony. Moreover, looking forward as well as back, he has, by considerately recording the places he has visited and the objects he has touched, made provision for a constant traffic in those pilgrimages and relics upon which the religion of the Mish-Mash, like all true religion, must depend.

The conclusion about Toynbee's self-perception seemed inescapable. "Has any other writer, however apocalyptic his message, taken such pains to acquaint the public with the trivial details of his own life, the successive signs of his Election, or to represent himself as the culminating end-product of one civilisation, the herald, law-giver, and prophet of another?" asked the palpably irritated Trevor-Roper. "Has any other Christian scholar thus applied to himself the successive incidents of the Christian myth?” (Trevor-Roper 1957:21-26). 


\section{THE DEBATE PROTRACTED:REACTIONS TO TREVOR -ROPER'S CRITICISM}

Trevor-Roper's blistering critique immediately drew rejoinders from readers who hailed from several parts of the world. Some were in letters to the editor of Encounter printed in the next four monthly issues of that periodical. It is impossible to gauge the exact nature of readers' reactions in general from those which were printed, of course, but the majority of those reproduced focussed less on the essential content than on the tone of Trevor-Roper's essay and what were perceived as ad hominem slurs.

Toynbee's son Philip was among the first to race to his father's defence. He opined that Trevor-Roper's "passionate outpouring” had been motivated more by rage and envy more than defensible scholarly factors. "It is well known that when little frogs in puddles look at larger frogs in ponds a glare of green and red light comes across their eyes”, sniffed the younger Toynbee. He accused the new Regius Professor of attacking his father as a "megalomaniac obscurantist and would-be messiah" rather than as a historian. The man who had sired and raised him, he insisted, was not the egotist portrayed in the recent essay. "After all, I have known this maniac intimately for forty years[,] and surely he must, at some moment of indiscretion, have let it out to me that he wished to be worshipped", recalled Philip Toynbee. "It would have been only fair to me to do so, for as the son of the new God I should myself have enjoyed some kind of divine status. I can only say that no such hint has ever been given to me". He added that anyone else who personally knew Arnold Toynbee would "have been laughing in quite the unintended way before he reached the end of $\mathrm{Mr}$ TrevorRoper's case-book material”. The son presented an immeasurably more flattering picture: "My father's modesty is famous - perhaps excessiveand I have had many personal occasions for testing its deep sincerity". Furthermore, "as for being obscurantist and religiously bigoted, as for lusting for destruction, all these charges will be equally grotesque to those who know him”. Philip summarised some of Arnold Toynbee's personal characteristics succinctly: “...he is a left-wing liberal in politics, uncertain but hopeful in religious belief, and a man of the utmost gentleness in private life” (Toynbee 1957:71). 
From outside the tribe readers also took up the cudgels and drubbed Trevor-Roper for his assumed sins. In Ottawa, for instance, W R Crocker, the High Commissioner for Australia in Canada, believed a fundamental question of competence had emerged. Trevor-Roper's article, he thought, "leaves no doubt about a decline in standards". This diplomat agreed that Toynbee needed to be challenged, but TrevorRoper's attempt to do so distinguished itself by combining "thinness of mind with ill-natured and ill-bred impertinence" on a "striking" scale. Crocker suggested that the Oxford historian had built his subsequent career on the infirm foundation of the "lucky assignment" given him in 1945 of reporting on Hitler's demise and regretted that his professional path had eventually led to his recent appointment to a prestigious chair "hitherto reserved for scholars of authentic achievement, like [Frederick Maurice] Powick [sic] and [V.H.] Galbraith”. With TrevorRoper as Regius Professor, the High Commissioner feared for "the standards of post-war Oxford". He failed to mention either the enthusiastic reviews which The Last Days of Hitler had received or any of Trevor-Roper's other scholarly achievements. In a parting shot, he thought that if Trevor-Roper was going to spend his time "pontificating journalistically on the world at large" rather than conducting serious research, he would be well-advised to emulate the work of a man more gifted with the pen (Crocker 1957:70).

Some of the combatants in the fray fought on explicitly Christian grounds. Launching his two-pronged counterattack from R A F Wyton in Cambridgeshire, Rowland Bowen found it highly regrettable that Trevor-Roper had chosen to assault Toynbee with a "crudely and offensively blasphemous parody of Christianity". That A Study of History envisaged great tribulations in the future of the West bothered him vastly less than it bedevilled Trevor-Roper. He acknowledged that Toynbee was a "short-term pessimist" with regard to Western civilisation but reasoned that such an attitude was virtually inevitable from a Christian perspective: "Our Lord promised us entry to His Kingdom in Heaven - He never promised a Kingdom of Heaven on Earth". Ergo, it was fully defensible for a Christian "to fear, and indeed prophesy, doom for existing man-made institutions". Calling TrevorRoper a self-disclosed "post-Christian", Bowen characterised his overarching attitude towards Toynbee as "the typical hate of the 
unbeliever for the believer". Turning to specific elements in the "splenetic" Trevor-Roper's essay, he thought the charge that Toynbee had neglected the history of the arts and science as well as administration and finance risible and possibly based on a failure to read the seventh volume of $A$ Study of History, much of which was devoted to precisely those subjects. Indeed, Bowen generalised, one could hardly read more than a few pages of any of the ten volumes without finding references to numerous artists of diverse kinds. "It is clear ... that Trevor-Roper has never read the book whose author he attacks”, alleged Bowen (Bowen 1957:70).

In the same issue of Encounter in which this grave indictment appeared, Neville Masterman of the University College of Swansea took Trevor-Roper to task for violating the principle of religious freedom he had recently espoused in his 1940 study, Archbishop Laud, 1573-1645. Writing in free verse, this historian professed:

"I hate your tedious trouncings, Trevor-Roper,

Laud's spirit in reverse now dwells in you.

The irreligious inquisitor

Is just as ugly as his opposite”.

Masterman counselled a more tolerant spirit when engaging with the works of other scholars:

Not everyone can view things as you wish.

We should be just to faiths that challenge ours,

If not proclaim'd with violence. Why not then

Just leave the gentle Toynbeean with his Mish Mash

Like those curious sects to dwell in peace.

In his new position as Regius Professor, Masterman believed, TrevorRoper could inculcate a broad-minded attitude in harmony with that of his heroes from the history of Western civilisation:

\section{FROM YOUR NEW EMINENCE, NOW CULTIVATE}

"The Erasmian spirit or the Platonists

You wrote so well about some time ago. 
Otherwise, Masterman feared, the consequences could be dire:

Men such as you, sceptics who thrive on hate

Strengthen the superstitions they abuse.

As Christian bigots of a former age

Caused infidelity, you, sir, will achieve

The opposite, new bogus faiths will form.

And truth? Who'll think there's such a thing as truth?”

(Masterman 1957:70-71)

Trevor-Roper also had his defenders. Among them was Nicolas Walter, an Oxonian who had just received a bachelor's degree in history at Exeter College and would subsequently become a relatively prominent humanist and anarchist. Incredibly, and uniquely among the respondents whose comments were published in Encounter, he insisted that the new Regius Professor had "not attack[ed] Professor Toynbee personally". Furthermore, to this recent graduate Trevor-Roper's detractors in the debate in Encounter had outdone him in terms of the vitriol they had hurled. Apart from what he found objectionable in the counterattacks, Walter insisted that most of the debate had been ineffective, for "no one has yet refuted Professor Trevor-Roper's accusations of determinism, obscurantism, and emotional prejudice" (Walter 1957:69-70).

Apparently weary of what he regarded as the unnecessarily acidic nature of the debate, Fredie A Mehta in Bombay attempted to steer an irenic via media and assist other readers in understanding a fundamental difference in Trevor-Roper's and Toynbee's respective points of departure. He wondered whether the former's critique "does not ultimately boil down to an attack against historicism as a method of scientific thinking" and "whether it pertains to the prophetic anticipation of a decline of a certain civilisation or to a prediction of the 'inevitability' of the triumph of State Planning or Totalitarianism over Democracy". Viewing Europe essentially as an outsider, Mehta thought that at base what had riled Trevor-Roper was that in preaching "prophecies of doom" of Western civilisation, rather than vigorously encouraging its permanence, Toynbee was in effect contributing to its 
demise. The Indian observer found an antecedent in the philosopher Karl Popper's monumental The Open Society and Its Enemies (Mehta 1957:70).

\section{CONCLUSION}

As Louise Orr, who knew Toynbee personally, wrote in the Dictionary of National Biography shortly after Toynbee's death in 1975, the magisterial professor was "untroubled" by the criticial views levelled at him by Geyl and Trevor-Roper, "since he had every confidence in his own" (Orr 1986:858). What he would make of the general religious situation in Europe and its lack of tolerance and reconciliation early in the twenty-first century is impossible to guess with confidence. Certainly the place of Christianity in this and other parts of the world has shifted dramatically during the decades since he wrote $A$ Study of History and delivered the 1952 Reith Lectures. Massive immigration of Islamic peoples has fundamentally altered the demographic profile of the United Kingdom and many continental European countries to a degree which has prompted guardians of the Christian legacy to call for a ban on such influxes in the interests of cultural preservation. Meanwhile, secularisation has continued apace, although Christian spiritual life remains strong in many quarters of what was once known as "Christendom". Elsewhere, the number of Christians has risen sharply in much of sub-Saharan Africa as well as in parts of Asia. The Soviet Union is no more, and traditional forms of Christian belief and practice have enjoyed a recrudescence in Russia, though both there and elsewhere in Eastern Europe secularising trends have also left their mark. What can be said is that in an era of so-called "globalisation" the once discernible boundaries of "Christendom" are much less distinct than they were in the 1950s and both in areas where Christianity was once the clearly dominant religion and elsewhere it now competes for with other faiths as well as secular humanism, materialism, and other persuasions in an arena of cultural and religious pluralism.

\section{Consulted literature}

Bowen R 1957. (RAF Wyton) to Encounter, undated, in Encounter, IX, no. 2 (August 1957), 70.

Crocker, W R 1957. (Ottawa) to Encounter, undated, in Encounter, IX, no. 2 (August 1957), 70. 
Fermor, P L and Taylor, C L “Toynbee, (Theodore) Philip”, in H C G Matthew and Brian Harrison (eds.), Oxford Dictionary of National Biography, LV. Oxford: Oxford University Press.

Geyl, P 1955. Debates with Historians Groningen: J B Wolters, and The Hague: Martinus Nijhoff.

Hale, F 2004 "Debating Toynbee's Theory of Challenge and Response: Christian Civilisation or Western Imperialism?", Acta Theologica, XXIII, no. 2, 23-44.

Kevin Sharpe (Warwick) Communication to Frederick Hale, 9 November 2004.

Kohn, H 1957. Is the Liberal West in Decline? London: Pall Mall Press,

Masterman, N 1957. (Swansea) to Encounter, undated, in Encounter, IX, no. 2 (August 1957), 70-71.

Mehta F A 1957. (Bombay) to Encounter, undated, in Encounter, IX, no. 4 (October 1957), 70.

Millar, F 2004 “Toynbee, Arnold”, in H C G Matthew and Brian Harrison (eds.), Oxford Dictionary of National Biography, LV. Oxford: Oxford University Press.

Orr, L 1986. “Toynbee, Arnold Joseph”, in Lord Blake and C.S. Nicholls (eds.), The Dictionary of National Biography 1971-1980. Oxford and New York: Oxford University Press.

Sharpe, K 1993 “Hugh Trevor-Roper, Lord Dacre”, History Today, LIII, no. 4, 45.

The Times, 27 January 2003 "Lord Dacre of Glanton” (obituary).

The Times, 6 June 1957. “Oxford Professor of Modern History”, 10.

The Times, 7 June 1957. "History Specialization 'Much Too Narrow”, 12.

Toynbee, A J 1954. (unspecified provenance) to The Times Literary Supplement, undated, in The Times Literary Supplement, no. 2,724 (16 April), 249.

-, 1954. A Study of History. X. London: Oxford University Press, 139.

-, 1960. A Study of History. Abridgement by D C Somervell. London: Oxford University Press.

Toynbee, P 1957. (Lindsey, Suffolk) to Encounter, undated, in Encounter, IX, no. 1 (July 1957), 71.

Trevor-Roper, H R 1957. “Arnold Toynbee’s Millennium”, Encounter, VIII, no. 6, 14.

-, 1963. “The Rise of Christian Europe”, The Listener, XXX, no. 18, 871. 
Walter N 1957. (Oxford) to Encounter, undated, in Encounter, IX, no.4 (October 1957), 69-70.

Wessels, A 1994. Europe: Was it Ever Really Christian? London: SCM Press Ltd. 